\title{
Dialogue
}

http://journals.cambridge.org/DIA

Additional services for Dialogue:

Email alerts: $\underline{\text { Click here }}$

Subscriptions: Click here

Commercial reprints: $\underline{\text { Click here }}$

Terms of use : $\underline{\text { Click here }}$

Virtue Ethics, Politics, and the Function of Laws: The Parent Analogy in Plato's Menexenus

Sandrine Berges

Dialogue / Volume 46 / Issue 02 / March 2007, pp 211 - 230

DOI: 10.1017/S0012217300001724, Published online: 27 April 2009

Link to this article: http://journals.cambridge.org/abstract S0012217300001724

How to cite this article:

Sandrine Berges (2007). Virtue Ethics, Politics, and the Function of Laws: The Parent Analogy in Plato's Menexenus. Dialogue, 46, pp 211-230 doi:10.1017/S0012217300001724

Request Permissions : $\underline{\text { Click here }}$ 


\title{
Articles
}

\section{Virtue Ethics, Politics, and the Function of Laws: The Parent Analogy in Plato's Menexenus}

\author{
SANDRINE BERGES Bilkent University
}

\begin{abstract}
Can virtue ethics say anything worthwhile about laws? What would a virtue-ethical account of good laws look like? I argue that a plausible answer to that question can be found in Plato's parent analogies in the Crito and the Menexenus. I go on to show that the Menexenus gives us a philosophical argument to the effect that laws are just only if they enable citizens to flourish. I then argue that the resulting virtue-ethical account of just laws is not viciously paternalistic. Finally, I refute the objection that the virtue-ethical account I am proposing is not distinct from a consequentialist account.

RÉSUMÉ : Peut-on construire une théorie de la loi à partir de l'éthique de la vertu? Qu'est ce qu'une bonne loi? Je dis que l'on trouvera une réponse à la question dans l'analogie entre les lois et les parents présentée par Platon dans le Criton et le Ménéxène. Dans $\$ 2$, je montre que le Ménéxène apporte une défense philosophique de l'argument que les lois sont bonne seulement si elles amènent les citoyens a la vertu. Dans $\$ 3$, je montre que cette théorie des lois selon la vertu n'est pas outre mesure paternaliste. Dans la dernière section, je réponds a l'objection suivante : que la théorie que je défend n'est ni plus ni moins qu'une théorie conséquentialiste.
\end{abstract}

Dialogue XLVI (2007), 211-30

(C) 2007 Canadian Philosophical Association/Association canadienne de philosophie 


\section{Dialogue}

\section{Introduction}

The past twenty years or so have witnessed the growth of a dialogue between ancient philosophers and philosophers writing on central contemporary issues in moral or political philosophy. This has been particularly true in the case of the renewed interest in character and virtue as ethical concepts, which has meant that many moral philosophers, such as Annas (2005a, 2005b), Anscombe (1997), Hursthouse (1999), and Slote (1995), have gone back to the philosopher they perceived as the founding father or their creed: Aristotle. Other scholars, notably Martha Nussbaum, seemed to believe that their philosophical perception could only be enhanced by their knowledge of ancient texts, be they from Aristotle, Plato, or the Greek and Roman Stoics. ${ }^{1}$

On the whole, and rather surprisingly, Plato's contribution to the creation of virtue ethics has been neglected, with a few notable exceptions. ${ }^{2}$ This is perhaps due to a focus on the part of readers on Plato's strong commitment to the thesis of the unity of the virtues, and on the somewhat extreme moral psychology of the Republic. ${ }^{3}$ Nonetheless, if we look at other dialogues, we may see that Plato does have very useful ideas to contribute to the discipline of virtue ethics, in particular with respect to more recent developments, a virtue-ethical approach to politics and the law. For this reason, I shall try here to shift the focus, not only from Aristotle to Plato, but also from the Republic to a lesser-known dialogue, the Menexenus. I shall offer exegetical analysis of this dialogue only insofar as it proves to be useful for understanding Plato's contribution to the debate on virtue and the laws.

In their introduction to Virtue Ethics Roger Crisp and Michael Slote note that there is a yet-to-be-filled gap in contemporary virtue ethics: "If virtue ethics cannot produce some plausible conception of social justice and of political morality more generally, then its main contemporary rivals, consequentialism and Kantianism, will have a distinct advantage" (Crisp and Slote 1997, p. 24). ${ }^{4}$

This article suggests how an advocate of virtue ethics might respond to this challenge by focusing on one central question that must be addressed by a virtue theory, namely, what is it for a law to be a good law? I will argue that a compelling answer is to be found in Plato's Menexenus, a dialogue often wrongly thought of as mildly interesting from a historical point of view but of little real philosophical interest - rather boring. This response appeals to the parent analogy, used also in the Crito to defend the view that a virtuous agent owes obedience to the laws. In the Menexenus Plato argues that laws are good insofar as they promote virtue in the city, just as parents are good parents, from the point of view of virtue ethics, if they encourage virtue in their children. As I hope to show, this response to the problem is a deep one, from which we can learn a great deal. 
This Platonic argument is closely relevant to modern debate in virtue politics, not just as a pointer for future debate regarding the justice of laws, but as a defence of existing claims such as that from Martha Nussbaum:

The idea is that once we identify a group of especially important functions in human life, we are then in a position to ask what social and political institutions are doing about them. Are they giving people what they need in order to be capable of functioning in all these human ways? Are they making it possible for citizens to function well? (1992, p. 214)

Nussbaum derives this conclusion from Aristotelian essentialism: Aristotle's conception of human nature is in many ways more fully worked out and more psychologically intuitive than Plato's theory of the tripartite soul (more so even than Plato's theory of the dual soul in the Phaedrus). Yet, the most promising argument needed to link claims about human nature to the function of laws is found in Plato's Menexenus rather than in Aristotle's works. If we want to argue not only that Aristotelian essentialism enables us to appraise laws in terms of their success at enabling flourishing, but that this is indeed the right and proper measure of success for a law, then we must turn to Plato.

This article is structured as follows: $§ 2$ argues that a plausible answer to the question "What would a virtue ethical account of good laws look like?" can be found in Plato's parent analogies in the Crito and the Menexenus. In $\S 3$, I show why two alternative virtue-ethical accounts of good laws - one account derived from the Republic and one offered by Michael Slote (2001) - are unlikely to work. In $\$ 4$ I argue that the Menexenus gives us a credible philosophical argument to the effect that laws are good only if they enable citizens to flourish. In $\S 5$, I argue that the resulting virtueethical account of good laws is not overly paternalistic.

\section{Virtue Ethics, the Law, and the Parent Analogy}

Virtue ethics is distinct from consequentialist and deontological ethical theories in that it attaches praise or blame not primarily to actions or types of actions, but to agents' characters. ${ }^{5}$ Thus it is difficult for a virtue ethicist to derive moral rules from the theory: just because $\mathrm{x}$ 's character is virtuous and $\mathrm{x}$ does $\mathrm{P}$ a lot does not mean that it is always good to do $\mathrm{P}^{6}$ This makes it awkward for the virtue ethicist to say anything sensible about laws. As Slote has noted, "because virtue ethics is supposed to concentrate more on the inner life of the individual than either consequentialism or deontology, one can easily wonder whether the former is really capable of doing justice to law or to any sort of objective or real constraint upon human action" (1995, p. 91).

This passage seems to express not one, but two, distinct worries. First, what would a virtue ethical account of political obligation look like? It 


\section{Dialogue}

would appear that whatever the virtuous agent judges to be the courageous/ just/temperate/wise course of action in a given set of circumstances is the courageous/just/temperate/wise thing to do. So laws are redundant: the virtuous agent has no need to be guided by them. What the virtuous agent will do is always guided by an understanding of the particulars of the situation in which one is required to act. It follows that the less than fully virtuous agent, who does not always know what the right thing to do is, cannot be guided by the laws either, as by their very nature laws fail to take particular circumstances into account.

The second obstacle to saying something about laws in a virtue-ethics theory is this: what could a virtue ethicist's account of a good law be? A consequentialist would answer that a good law maximizes happiness, and a deontologist might say that it treated everyone as an end in themselves, but no such extension of the theory seems available to the virtue ethicist. An agent is good if she has a good character, i.e., if she is psychically healthy, or has achieved harmony amongst the different sources of her motivation. It seems that it would be difficult to transfer this account to laws without an unacceptable degree of anthropomorphism, that is, treating laws as if they had characters which could evolve of their own accord through habituation. ${ }^{7}$

I argue that the way out of the virtue ethicist's difficulties in dealing with laws is a certain model used by Plato in both the Crito and the Menexenus. In particular, I will show that the parent analogy as it figures in the Menexenus can help us answer the question "What is it for a law to be good?" If one reads the Menexenus in isolation, the crucial role of the parent analogy might go unnoticed. If, however, one reads it together with the Laws speech of the Crito, it is difficult not to see its significance. ${ }^{8}$ Thus, I want to introduce the parent analogy by first saying a few words about its use in the Crito, since this sheds important light on the project of the Menexenus.

In Crito 50c-51c, ${ }^{9}$ Plato presents an argument for the conclusion that Socrates owes the (personified) Laws of Athens obedience even when they command that he should die. The Laws, Socrates claims, have been as a parent to him in that they have provided for his nurture and education:

Since you have been born and brought up and educated, can you deny, in the first place, that you were our child and servant, both you and your ancestors? And if this is so, do you imagine that what is right for us is equally right for you, and that whatever we try to do to you, you are justified in retaliating? (Crito 50e)

A coherent interpretation of the argument summed up in this passage suggests that the duty to obey is not grounded in respect or gratitude that a child owes a parent, but in the child's natural duty to obey. But what can we understand by this natural need? The Laws at Crito 53e ask Socrates to 
consider what will happen to him and his children should he take them to exile into Thessaly, the home of "indiscipline and laxity," and the Laws comment that their lives would be like one long banquet and moreover they would be the object of laughter and ridicule. Would they not have a better chance of becoming good citizens if they remained in Athens among Socrates' friends, to be brought up according to the same laws as their father? A city that does not have strong or good laws is not a good place for bringing up children, the Laws suggest. Obedience answers the child's need to become habituated in order to develop a virtuous character. A parent who does not require the child to obey consistently may not provide the child with what he or she needs to become virtuous. Habituation requires repetition, and repetition requires external influence in the form of parental authority. For example, a child will not share her toys of her own accord, yet she will not become a successful person unless she learns to share. So it is in her interest to obey her parents' commands to let other children play with her favourite toys until she is able to appreciate for herself that sharing has its good points and that not sharing leads to not having any friends.

Similarly, the reason a virtue ethicist might give for obeying the law (and this, I believe, is one reason Plato in the Crito presents for consideration) is that the laws guarantee the conditions necessary for flourishing in the city. In other words, it provides the framework or environment for an agent to develop into a successful, virtuous citizen. This is why the Laws are right to suggest at Crito 53e that Socrates would be unwilling to have his children brought up in Thessaly: such a city would not provide the framework required for them to become virtuous adults. It follows that when there is a legal framework that is conducive to virtue, to disobey the law is to harm one's own potential for flourishing. It is also to harm another's potential for flourishing because it endangers the framework necessary for all to flourish.

The parent analogy in the Crito illustrates how external constraints can be relevant to achieving virtue without requiring justification by appeal to objective, universal moral laws. First, it is clear that good laws in a virtuetheoretical sense do not correspond to some ideal blueprint. It is not open to a virtue ethicist to write a treatise in which she will list all possible good laws. Which laws are actually good needs to be worked out within the society to which they apply, i.e., taking into consideration what is needed to achieve flourishing in that society, and what threats there are likely to be. The virtue ethicist's practical import can only be contextual. ${ }^{10}$

Second, the parent analogy shows that laws derive their authority from need: they enable our flourishing. What parents say goes, not because they represent a universal law which they are passing on to the child for use in adult life, but because they are training the child, habituating her, and the best way to inculcate good habits into someone is to rule by laws.

Any argument that the law is to the citizen as the parent is to the child is very obviously open to charges of paternalism. Paternalism implies a stated 


\section{Dialogue}

claim that something is good or bad for you even if you do not know it is, and there is an intent to force that something upon you. More straightforwardly, the worry is that by appealing to the parent analogy to explain the relationship between laws and citizens, we end up implying that laws should treat citizens as if they were children who do not know what is good for them and who have to have decisions made on their behalf. If this is what the analogy is meant to convey then in a sense it must fail. ${ }^{11}$ Paternalism has no place in answering philosophical questions about the role and place of laws because it is not the case that most people would accept (or have good reasons to accept) an idea of themselves as children unable to decide for themselves what constitutes the good or virtuous life, or enable them to lead it. Although some people might be unable to do so in practice (because their life is not conducive to reflection), and some people might be unwilling to do it, most people would claim, rightly, that they are in principle capable of making decisions that contribute to the good life. Hence, a philosophical account of laws that relied on paternalism would be unacceptable.

However, I argue that Plato successfully uses the parent analogy in the Menexenus to answer the question "What is it for a law to be a good law?" from a virtue-ethics perspective. This question is distinct from, but as equally important as, the question the Crito addresses, i.e., "Why should we obey the law?" As one argument of the Crito seems to suggest, it is at least conceivable that we would have good reason to obey a law that is not good because to disobey it would, for example, undermine the authority of the state and we believe that this authority is on the whole legitimate (Crito 50ab). Thus, an answer to the question "Why should we obey?" does not necessarily give us an answer to the question "What makes a law a good law?"; so, what the Menexenus has to say about what makes a law a good law is crucial to the project of virtue politics.

\section{Alternative Accounts: Slote and the Republic}

I consider here whether there is a virtue-ethical account of what it is for a law to be good available in a more obvious source than the Menexenus. One such source is Plato's conception of the good state in the Republic, and another is Michael Slote's writings on virtue ethics. I will show that neither of these sources gives us a satisfactory account of good laws.

The first, most obvious place to look for a virtue-ethical account of a good law, it seems, would be the Republic, where Plato talks at great length of what it is for a state to be a good state, based on his definition of what it is for a character to be good. The focus of the Republic is, by turns, on the soul and the organization of the form of the ideal state. Although in the latter capacity it describes at length the political organization of the city and the rationale for distributing political responsibility, it does not really say much about laws. It is therefore not a source which we can obviously contrast with the Crito and the Menexenus, which are specifically about laws. 
Moreover, we cannot simply say that a good law is a law passed by a good state, as it is not clear either that any law passed by a just state must be just, nor that an unjust state cannot pass just laws. There is nothing unjust about the French law which proclaims a certain day in May as Mother's Day, even though that law was passed by the Vichy government. On the other hand, the British law stipulating that London cabs must carry a bail of hay at all times is unjust despite having been passed by a government which was not obviously unjust. The point is that laws have to be assessed in the sociopolitical context in which they are applied, and this may be very different from the socio-political context in which they were created. So, while a good legislator may be a good judge of his or her society's needs at a given time, he or she cannot guarantee that the law will remain just at all times. This is why we need to be able to say more about what makes a law a just law, and why the Republic cannot provide us with an account.

Of course other dialogues besides the Menexenus and the Crito address the problem of laws. The Laws also features a parent analogy as part of an argument for the conclusion that the legislator's main task is to promote wisdom, i.e., make sure that citizens are in a position to choose for themselves the best life they can (Laws 687d-e), something I discuss more fully in $\S 5$. In the Statesman, Plato seems to suggest that laws would have no room in an ideal state, because perfect statesmen should be flexible in their rule, and treat each case according to its merit (294a, 300c). This suggestion is highly interesting because it takes seriously the incompatibility between virtue ethics and the rule of law. But the dialogue twists and Plato goes on to argue that in the absence of the true king, what we must do is obey existing laws without ever questioning or changing them. I have argued elsewhere (Berges, unpublished) that the Statesman is another of Plato's attempt to reconcile laws with virtue. On close inspection, it seems that what Plato is doing in that dialogue is defending the rule of laws, when it works hand in hand with equity. In other words, we should accept to be ruled by laws even if we know it is impossible to achieve a set of perfect laws, but at the same time we ought to be able to respond to particular cases in the way the true king does.

A close reading of the Statesman and the Laws would no doubt add greatly to my interpretation of the Menexenus and the Crito, and to a virtueethical account of just laws. In any case, they seem better sources than the Republic for reasons stated above. However, the Menexenus and the Crito, with their explicitly and extensively developed use of the parent analogy, remain the most straightforward Platonic sources for beginning our investigation into the possibility of a virtue-ethical account of good laws.

In his discussion of the punishment of war crimes, Michael Slote argues that a law is just if it is put forward by a lawmaker whose intentions are just: 


\section{Dialogue}

Thus national legislators who pass a law may do so for many different possible reasons, but we might want to say that if they do so out of a desire for the public good, or the good of their country, then the law they pass is justly enacted and is a just law; whereas, if they act from greed or narrow sectarianism, then they don’t act justly and the law they pass is tainted with that injustice. (2001, p. 79)

At first sight, Slote's argument looks a bit dubious: good intentions do not necessarily make good laws. At the very least the lawmaker has to be virtuous, i.e., in a position to judge what effects a law will have on citizens so that the good intention can be realized in practice.

But even with the above amendment, the account remains unsatisfactory. Slote is using the premise that in virtue ethics an action is praiseworthy if it is performed by a virtuous agent; in other words, actions derive their value from the state of the character of their performer. As passing a law is an action, it derives value from the character of whoever passes it, i.e., the lawmaker. However, Slote fails to note that a law is distinct from the act of passing a law, and thus a lawmaker may act justly in passing a law, and, at the same time, that law may be unjust. This is clearest if we consider that laws age and that a law passed by a just lawmaker may come to be quite rightly regarded as unjust, simply because the circumstances in which it is applied have changed, or our perceptions of them have evolved. Once again we can cite the example of the taxi and bail of hay. It may have been a wise move at the time the law was passed to ensure the working horses of London were well fed, but, clearly, the lawmakers did not envisage that the law would soon be redundant because taxis would no longer be horse-driven. Equally clearly, it was not a failure of wisdom on their part they did not envisage this: the prediction of scientific innovations and their social and moral implications is not part of being virtuous.

Because it would not have been possible for the most virtuous of lawmakers to foresee that the law would one day become unjust (for a law which allows taxi drivers to be fined nowadays for not carrying a bail of hay is unjust), then it cannot be a sufficient condition of a law being just that it should be passed by a virtuous lawmaker. ${ }^{12}$ Once again, we can conclude that the argument in the Menexenus remains the best source for an account of what makes a law a good law.

\section{The Argument in the Menexenus}

I turn now to the argument given in the Menexenus to the effect that a law is just if it is capable of producing virtuous citizens. The Menexenus can be divided into four parts. The first, 234a-236c, introduces an unusual theme: Socrates, on the verge of making a speech, claiming to be good at speechmaking despite all he says about rhetoric in the Gorgias. ${ }^{13}$ The second part, 236d-239a4, describes the origins of Athens and the Athenians. Plato argues that the earth and the city of Athens are the true parents of 
the Athenians, from which it follows that all Athenians are brethren and thus should have equal political status. The third part, 239a5-246a, gives a curiously anachronistic and heavily revised history of Athens. If any part of the dialogue is meant to be taken as either parody or political commentary then surely this is it. At least one commentator has read this passage as a direct criticism of Athenian policy at the time it was written. ${ }^{14}$ The last part, 246b-249c, on the other hand, is the most obviously philosophical part of the dialogue. Socrates uses it to speak in the voice of dead soldiers passing on a message to surviving parents, children, and to the state. Platonic themes such as the unity of the virtues (246e) and justice as temperance $(248 \mathrm{a}-\mathrm{c})$ are prominent, and, as I will try to show, there is an important philosophical argument in this passage.

Commentators who see some serious import in the Menexenus tend to think that it is of a political nature rather than philosophical. In particular, both Huby (1957) and Kahn (1963) read the dialogue as a political pamphlet, one meant to shame the current Athenian government into changing some of its recent policies. They support their views with plausible historical analysis of the dialogue and I do not wish to argue against them. Nonetheless, I believe that the dialogue also contains a self-standing philosophical argument to the effect that laws are just only if they enable citizens to flourish. ${ }^{15}$

The argument presented in the Menexenus, like the argument in Crito $50 \mathrm{c}-51 \mathrm{c}$, is an argument by analogy, and it draws a conclusion about what it is for a law to be a good law from a premise about what it is for a parent to be a good parent. The conclusion of the argument is that the measure of a good legal system is its success at producing virtuous citizens. This conclusion is presented both implicitly and explicitly in the dialogue. It is explicit at the end of the second part of the dialogue, where Socrates links virtuous men and good governments: "For government is the nurture of men, and the government of good men is good, and of bad men is bad. And I must show that our ancestors were trained under a good government and for this reason they were good" (238). At this point in the dialogue, the conclusion is not wholly supported, but the analogy is under way: Socrates has already argued that Athens is a mother to the Athenians and that a mother's function is to nourish and nurture. He proceeds to make it clear that the nurturing of citizens consists in making them virtuous, stating that the city will be responsible for turning war orphans into virtuous citizens:

While they are children she [the city] is a parent to them, and when they have arrived at man's estate she sends them to their several duties, in full armor clad; and bringing freshly to their minds the ways of their fathers, she places in their hands the instruments of their fathers' virtues. (249a) 
This is an implicit statement of the conclusion: if the laws of Athens are good, this is what they should do, i.e., care for the virtuous growth of citizens. The implied criticism, in the face of proposed reform, ${ }^{16}$ is that the laws are not doing this as they should, and therefore are no longer good.

To sum up, the argument Plato uses in order to support the conclusion that a good law is one which nurtures virtue starts off with premises about what it is to be a good parent. As for the conclusion, the premises can be found (explicitly) in the second and (implicitly) in the fourth parts of the dialogue. In the second part of the dialogue, Plato makes the offensive claim that a mother who does not feed her infant is no mother at all (237e). This is not, however, a random misogynistic comment, but an unfortunately worded claim about the function of parenthood leading to the conclusion that the measure of a good parent is his/her ability to bring up children who are successful human beings, i.e., healthy and virtuous. (Presumably, prior to the existence of powdered milk, and absenting a wet nurse, a mother who was unable or unwilling to feed her baby would not have had much success at keeping it alive). A second premise is implicit in the fourth part of the dialogue, the prosopeia (discourse of the dead) where Plato claims that the best reward for parents is not to be grieved upon their death by their children, but that their children honour them by living as well, i.e., as virtuously, as they can (247a). Grief should not be excessive and efforts at virtue must be increased in order to properly honour one's dead fathers. This implies that a successful parent is one whose children are virtuous and so supports the conclusion we got from $237 \mathrm{e}$.

Hence Plato's parenting analogy: a successful parent is to virtuous children as a good legal system is to the virtuous citizen of a city. The dialogue is rife with references to the analogy, most notably at 237b: "And the country which brought them up is not like other countries, a stepmother to her children, but their own true mother; she bore them and nourished them and received them, and in her bosom they now repose." This passage gives us the core of the analogy. Family relationships are rooted in nature and need: the mother is by nature best suited to provide for the infant. In the same way, the land by nature provides food for its inhabitants (237e-238a) and gods to educate them, and enables them to grow strong enough so that they may govern themselves (238b-c). Thereafter the land and the city jointly provide for and nurture the citizens of Athens: the city educates them (238c) whilst the land carries on her task of feeding them and receives them when they die (237b). This echoes the passage in the Crito (50c-d) in which the Personified Laws of Athens point out to Socrates that they have held a function both similar to, and higher than, that of parents by enabling his progenitors to marry and start a family, and by providing for his education. In both dialogues, the City is presented as natural, that is, something that can be viewed and judged in terms of the functions it fulfills. 
This reading of the analogy may be challenged. When Plato talks of the city being as a parent to the children of the diseased soldiers, he may be appealing to a different argument altogether: the soldiers lost their lives for the city, and as a result their children are orphans. The city is therefore obliged to replace, or even serve as, the lost parents as well as it can. More strongly put, an agreement is hinted at between the city and the soldiers it sends to war: the soldiers risk their lives on the understanding that the city will look after their children if they die. But this argument is not by itself sufficient to show that the city can be as a parent to the war orphans: it has to be the case that it is capable of being parent-like. I may promise a friend that if he dies I will look after his business. But if I do not have a good head for business, I will not be able to fulfill my promise. In the same way, if the law is to be in loco parentis to the children of the dead, then it must be in some way parent-like, i.e., it must be capable of fulfilling the function of parenthood. This will clearly be the case if the city is as a parent to citizens anyway: when the soldiers die, it is only required to be more particular in its care of the orphans, but it fulfills some kind of parenting function for all citizens anyway. ${ }^{17}$ Together with the passage at $238 \mathrm{a}-\mathrm{c}$, and, in particular, Plato's claim that "government is the nature of men," following the analogy of the land and a mother, it is clear that Plato intends for us to see the city as a parent of citizens, one who is able to carry on the work started by the land (feeding and educating sufficiently so that we may feed ourselves and create a city for ourselves) by educating citizens to virtue.

\section{Why the Virtue-Politics Account Is Not Overly Paternalistic}

There are several things we might mean by paternalism, and various objections we might hold against it. Here I will concentrate on one particular kind of paternalism which seems to come with a virtue-ethical theory of laws, a kind which presents a threat to our ability to choose for ourselves the best life we can. The anti-paternalistic position virtue ethicists would be up against can be outlined as follows. Parents make choices for children because children are not capable of choosing the best for themselves as they are not yet fully rational. But once they reach what is commonly agreed to be the age of rational maturity, or adulthood, their parents are no longer entitled to choose for them. ${ }^{18}$ In the same way, laws cannot rule over an adult's life choices - provided these do not harm others. ${ }^{19}$ That is, they have to respect what Joseph Raz refers to as people's ability to "shape their life and determine its course" and to be "creators of their own moral world" (1986, p. 154).

Of course these abilities are already seriously limited by various uncontrollable aspects of our culture and environment. Being born in a certain part of the world, into a certain social class, to a particular religion and at a particular time, and being born a male or female all affect the choices we are able to make. Nonetheless, if the law makes it impossible for an indi- 
vidual to question her moral beliefs and to decide for herself whether she wants to renew her allegiance to them, then that law is threatening her autonomy in a way that her cultural background is not. In the modern world it is plausible that a cultural background should be partially rejected or modified to suit individual choices without risking anything other than censure ${ }^{20}$ but to reject a law is to become a criminal, to put oneself in a position where society has a right to exact revenge and impose its conception of the good. ${ }^{21}$ A good liberal can hold that the shackles of tradition are meant to be shaken or broken-not so those of the law.

The idea that there should be virtue-promoting laws is especially open to the kind of anti-paternalist objection I have described. If laws promote virtues, then there seems to be a very clear sense in which they do not allow individuals to create their own moral world. For example, they would not encourage an individual to flourish as a controlled intemperate, someone who allowed himself to drink, eat, and take drugs to excess, even were there nobody around who might be harmed by his behaviour. This person would have been taught, at an early age, that intemperance was a vice, and that moral worth was not to be measured by the consequences of one's actions, but by the state of the agent's character. So, more generally speaking, people could not choose to shape their lives according to consequentialist or deontological theories. People who lived under virtue-promoting laws would not be the "creators of their moral world."

But of course the virtue-promoting laws need not be coercive: they do not put people in jail for behaving in ways that encourage the development of vices, or that do not encourage the development of virtues. ${ }^{22}$ Living in an intemperate manner (if no one else was harmed) need not be a crime, and the person who chose to live in that manner would not be punished. But my point is not that somebody's attempt to live according to different values would be thwarted by the laws, but that nobody would even think of challenging the moral world in which they were born. This is not equivalent to saying that people are shaped by their cultural, social, and family background, and is therefore not open to the reply that people are often challenging the values they were given as children. If moral education were directed by the state, then the usual pathways through which one comes to challenge one's values would be closed: one would simply not be able to discuss different value systems and different moral theories with people who had been brought up differently. The uniformity of moral formation would make it much harder for people to choose their own moral way of thinking.

Having stated the objection as strongly as possible, I will now endeavour to show that a virtue ethicist who takes her cue from Plato's parent analogy can successfully reply to it. Legislating on the principle that the good life is the virtuous life endangers people's autonomy. It is nonetheless true that autonomy requires the capacity to choose, that is, being informed about 
what choices are available, being able to reflect on the short- and long-term consequences they are likely to have, and on whether our several choices are compatible with each other. It follows that one virtue - wisdom - may be promoted without endangering autonomy: on the contrary, promoting wisdom is tantamount to helping people become more autonomous. If the virtue ethicist can limit her claim to the idea that laws should be wisdompromoting, then the paternalism threat disappears. ${ }^{23}$

In order to show that the virtue ethicist can do just that, I turn once more to a parent analogy in Plato, but this time to the one in the Laws. In Book III, 687d-e, the Athenian describes a father's attitude to his child's dreams as one of fear and worry that they should come true. This passage is suggestive. The twenty-first-century parent often shudders at his child's ambitions, whether it be to become a soldier or a princess - equally frightening prospects. The parent does not necessarily see her role as removing these ambitions and replacing them with suitable ones. Nor does she encourage them or just wait and see whether they come to be realized and then bemoan the fact that they have. The parent's wish in Plato's Laws is this: that his child may acquire enough wisdom so that he may, come the time, make the best choices. Parental intervention thus takes the form of teacher of wisdom. In true Plato style, this example is then used as an analogy for the law/citizen relationship:

I, for my part, urged that this is an injunction to legislate with a view to one single virtue out of four. He should keep them all in his view, I said, and in the first place that virtue which brings all the rest in its train, that is, judgement, intelligence, and right conviction attended by appropriate passionate desire. (Laws III, 688a)

The Laws' proposal deflects paternalism without losing any ground for virtue ethics. Either Plato is right that the good life is the virtuous life or he is wrong. If he is wrong then the effect of wisdom-promoting laws will not be to impose the virtuous life as the best life, but merely to put people in a position to choose for themselves which life is the best life (as long as it is not harmful to others). So people will be able to "create their own moral worlds" and live according to consequentialist, deontological, or other moral norms.

If Plato is right when he says that the virtuous life is the best life, then wisdom-promoting laws will ensure that individuals flourish without endangering their autonomy. This is true whether or not we accept the unity of virtue thesis. If we do, then we believe that a wise person will necessarily be courageous, temperate, and just. But if we do not we may still claim that someone who is wise will realize for herself that she needs virtue to flourish and, helped by her wisdom, will seek the virtues. Either way, 
the wisdom-promoting laws do not impose on the subject a conception of the good, but rather help her seek and achieve her own.

The claim that laws should be wisdom-promoting gives us a minimalist kind of paternalism. The laws do not make it their business to teach all citizens to be virtuous. On the assumption that wise people will know what is best for them and make the right choices, the laws only need to ensure that wisdom prevails. This leaves the law with two main tasks: to educate the young into wisdom, and to preserve a peaceful, stable, and prosperous environment in which wisdom may be sustained. This covers laws on education and laws which prevent harm to others, but it is not obvious that this virtue-ethicist account will warrant other laws: it will be expected that citizens who have been properly educated will on the whole know how to make the right choices. If the system fails them and they make choices that threaten others, then they are faced with the laws designed to protect the environment, and these laws will therefore act as a deterrent or, failing this, as protection. Thus the account I have described, according to which the function of laws is to promote wisdom in the community, gives us a very minimalist legal system — one even Mill might find acceptable.

Of course, this is still paternalism of some kind, as the law's role is not value-free, and laws do impose some conception of the good upon citizens. At the same time, it must be very difficult to claim convincingly that one has no need to be wise, and that it is nobody's business but ours if we do not choose wisdom for our children. In other words, if the argument in the Laws suggests paternalism, it is not the kind of paternalism which we ought to reject. If we combine this reading of the Laws with the argument in the Menexenus, then we are left with a parent analogy which is not viciously paternalistic on account of imposing a conception of the good on citizens which leaves them no room for personal choice. The parent analogy, I conclude, cannot be rejected on grounds that it is unduly paternalistic.

\section{Conclusion: Plato and Modern Virtue Politics}

In the introduction I stated that virtue ethics cannot appeal to external constraints derived from universal objective laws. This could mean that the future of virtue politics is very limited, i.e., that it cannot explore one important avenue in political philosophy - the justice of laws and political obligation. Plato, in the Menexenus, shows how we might sidestep this difficulty and give an account of what it is for a law to be just by appealing to the parent analogy. Just as a successful parent is one whose children grow to be virtuous, a successful legal system is one which promotes wisdom in the city, thereby ensuring that citizens are able to pursue virtue and flourish. In both cases we have a measure of success that is firmly grounded in considerations of citizens' characters. 
By putting forward and defending the conclusion that the measure of good laws is their success at producing wise or virtuous citizens, Plato offers a plausible solution to the problem posed at the beginning of this article, namely, whether virtue ethics can say anything about what makes a law a good law, and thus whether it can compete with Kantianism and utilitarianism in the political domain. However, my answer to the challenge is open to the following objection. Is there anything that is specific to virtue ethics in the solution offered here or could it be achieved equally, and more easily, through a consequentialist argument?

The reply to this objection can only be to bite the bullet, so to speak. However, the bullet is a soft one. True, a consequentialist with a deep concept of happiness ${ }^{24}$ and a commitment to virtue theory ${ }^{25}$ could come up with a very similar account of just laws, one which made the same points, and even relied on the same analogy and the same texts. But this does not mean that the virtue-ethical account is redundant and should be abandoned. On the contrary, if a virtue-ethical account can inform accounts from rival theories, then its richness ought to be celebrated and we should seek to develop it further. ${ }^{26}$

\section{Notes}

1 For example, Nussbaum's discussions of cosmopolitanism are inspired by the writings of Marcus Aurelius and Cicero, and she draws her version of the capability approach from Aristotle's theory of human nature. See her 1996, 1997a, 1997b, 2000, and 2003.

2 See Michael Slote (1999); Julia Annas (2005b), whose discussion of the concept of wickedness is based on a reading of Books 8 and 9 of the Republic; and Christine Korsgaard (1999), who bases her discussion of self-constitution on Plato.

3 This is perhaps why Philippa Foot, in her pioneering book Virtues and Vices (1978), claimed that she found Plato less useful than Aristotle when talking about the virtues.

4 Crisp and Slote noted that at the time they were writing, progress was already being made in that area. Progress continues nowadays, with Nussbaum and Slote being the leading writers in the field of virtue politics. It is interesting to note that by the time Virtue Ethics was published, Nussbaum had already written one influential article on virtue politics, "Human Functioning and Social Justice: In Defence of Aristotelian Essentialism” (1992).

5 For more on this, see Slote 1995, p. 92.

6 However, see Rosalind Hursthouse (1996) on why virtue ethics can accommodate some moral laws.

7 At a push we might apply the theory to the city, as Plato does in the Republic, i.e., that a just city is one in which the parts are working together in harmony. As a city is made up of people, the anthropomorphism is less worrying. 
8 Sara Monoson, who mentions the Laws' speech in the course of her discussion of the Menexenus (1998, n.46), sees that the parent analogy (or the familyrelationship model, as she refers to it) plays an important part in the dialogue, particularly regarding the argument for the autochthony and equality of the Athenians and the bond that exists between citizens and city, a bond that leads some citizens to lay down their lives willingly for the city on the understanding that the city in return will care for their surviving family: "The Menexenus thus suggests that Athenian norms of family obligation can best guide one in understanding how to maintain honourable, reciprocal relations between the city and citizens" (p. 504.) Monoson contrasts the family model to the lover model favoured by Pericles in Thucydides's Funeral Oration, and argues that Plato is consciously opposing the Periclean model.

However, although Monoson advises that we compare the family model in the Menexenus to that suggested in the Crito, she does not draw any significant philosophical conclusions from the use of that model in either dialogue. I believe that if we take her advice seriously and use the Crito to understand the Menexenus, we can achieve a much deeper and more interesting understanding of the latter.

9 All references from the dialogues are taken from Plato 1989. Note that I argue that the use of the parent analogy in Plato's Crito answers the question "Why do we owe the laws obedience?" in Berges 2004.

10 It may seem that the idea that there can be no blueprint for laws is in contradiction with Plato's view in the Republic that the Form of the Good is the blueprint for everything that is good, including the city. However, the Form of the Good need not specify what each thing that is good has to be like in detail, but only that it should fit in the overall picture. Plato himself avoids specifying that there be too many laws when he describes the ideal city; he merely states that there should be laws regarding this or that.

11 In §5 I shall argue that the parent analogy as it is used by Plato is not viciously paternalistic in that its emphasis is on the flourishing of children and citizens rather than on expectations of obedience.

12 Here one may object that Slote's argument is best understood as a methodological point than one about sufficient conditions. The best way to ensure that just laws are passed is to have just lawmakers. Close reading, I think, does not bear this out as Slote's claim is phrased in such a manner as to suggest he is looking for sufficient conditions: "if the law is passed justly . . . then it is a just law" (2001, p. 79). If, however, Slote is making a methodological claim, then his point is question-begging as far as the present inquiry is concerned (although this is not to say that it is a question-begging point taken in its own context, i.e., the treatment of war criminals) because it does not tell us what makes a law a just law independently of our appraisal or the lawmaker's character; it tells us merely that just lawmakers make just laws.

13 The fact that Socrates claims he is merely repeating a speech written by Pericles' mistress may also be contrasted with his denunciation of recitation in the Ion. 
However, as in the last lines of the Menexenus it becomes clear that the speech is very probably Socrates' own, the contrast is not necessarily significant.

Also introduced are grounds for thinking that the speech to follow is going to be to some extent a parody of Pericles' funeral oration as reported by Thucydides. For textual and historical support for the parody view, see Huby 1957, Kahn 1963, and Monoson 1998. All three recognize that there is some amount of parody in the dialogue directed at Pericles and Thucydides, but, at the same time, they do not share A. E. Taylor's view (1960) that the whole dialogue must be read ironically. All seem to agree that at least the last part of the dialogue is meant to be taken as a serious piece of philosophy.

14 Pamela Huby (1957) read this as a political pamphlet designed to shame Athens for her recently created policy of seeking to cut back state support for war orphans.

15 That there should be such an argument is compatible with the view that the dialogue criticizes Athenian policies, especially if Plato thought that those policies no longer supported the virtuous life in Athens. In particular, the strong injunction at 248d-249a, namely, that the city should care for the children of the dead as parents would, thereby giving them the means to become virtuous citizens, can be read both as a reminder of Athens' duty toward the children of the dead (especially topical if Athens was then in the process of revising the relevant laws) and as part of an argument designed to elucidate what it is for a law to be a just law.

16 See Huby (1957, pp. 107ff.) for the historical note regarding the proposed reforms.

17 Monoson suggests a different role for the analogy of motherhood and land, namely, that it is used by Plato to support the conclusion that all Athenians are related (1998, p. 500). While this is a plausible interpretation, it seems that it does not preclude a role for the mother/land analogy in determining the city/parent analogy.

18 Here I follow Locke: "Their parents have a sort of rule and jurisdiction over them when they come into the world, and for some time after, but it is but a temporary one. The bonds of this subjection are like the swaddling clothes they are wrapped up in and supported by in the weakness of their infancy; age and reason, as they grow up, loosen them, till at length they drop quite off and leave a man at his own free disposal" (1952, p. 55).

19 This position is supposed to be reminiscent of Mill's "harm to others" principle (cf. 1991, p. 14) to the effect that the only purpose for which power can be rightfully exercised over any member of a civilized community, against his will, is to prevent harm to others. His own good, either physical or moral, is not a sufficient warrant. He cannot rightfully be compelled to do or forbear because it will be better for him to do so, because it will make him happier, because in the opinions of others, to do so would be wise or even right. One way of supporting Mill's position (though not Mill's own) would be to apply Locke's view: parents have dominion over children's choices just because children are not fully rational. So, given a mature adult, there are no reasons why anyone should dictate to her what is best for her. 
Another argument is available for this particular anti-paternalistic position: to impose life choices on individuals over and above their expressed preferences is wrong because we have no real way of knowing what is good for people beyond what they claim to prefer (see Hamlin 1993, pp. 653-54).

20 I do not want to underestimate how significant a threat to autonomy censure might be; my point is that it is distinct from the threat of laws.

21 The contrast is less obvious if we consider non-coercive forms of paternalism of the kind defended by Chan (2000), i.e., where the laws encourage certain choices without coercion by rewarding those who make them. However, such laws are also more difficult to challenge than one's own culture. Imagine, for instance, being a smoker in a part of the world where cigarettes are very expensive, there exist important tax breaks for non-smokers, and schools teach people to demonize smokers: if you choose to continue to smoke, you feel as though you have to stand up against a culture that is state-sanctioned, if not state-created. This makes it doubly hard to challenge it.

22 One crude objection to the claim that laws should be virtue-promoting is that people would be rounded up for not leading virtuous lives. Not so! - virtuepromoting laws would have to educate the character, and, as Aristotle has shown, this is best done through repetition, and then conscious and willing habituation; spending time in prison does not achieve that. More insidious, perhaps, is the objection that virtue-promoting laws would licence the jailing of people on grounds that they were bad examples for other citizens. But this would have the same effect of forcing people to behave in a certain way because they were afraid of being punished. Again, this effort at pretence would probably prevent their character from maturing as it should.

23 One could also make a case for the other virtues. Arguably, courage is needed for autonomy: one needs to be courageous to stick to the choices one believes to be the right ones. Temperance may also be necessary if one is to weigh the pros and cons of a lifestyle or course of actions without being swayed by temptation of short-term enjoyment. And of course, one could argue that no choice is the right one unless it is just, and that all we need in order to make the right choices is to be able to avoid injustice.

24 See, for example, Griffin 1986.

25 A commitment to virtue theory does not entail a commitment to virtue ethics; one may take the virtues seriously without thinking that they must be the central ethical concept (i.e., before consequences or duties). See Driver (1996) for a virtue theory that is not a virtue ethics.

26 I follow Rosalind Hursthouse, who in her On Virtue Ethics takes this view of rival theories sharing conclusions and arguments: "And if they [utilitarians and deontologists] were to agree, and their only protest was 'but we can say that too-that's a utilitarian (or deontological) thesis,' I should not be inclined to argue at all; I should be delighted. Let us by all means stop caring about how we distinguish ourselves and welcome our agreements" $(1999$, p. 7). 


\section{References}

Annas, J.

2005a “Virtue Ethics: What Kind of Naturalism?" In Virtue Ethics, Old and New. Edited by S. Gardiner. Ithaca, NY: Cornell University Press, pp. 11-29.

2005b "Wickedness as Psychological Breakdown." Southern Journal of Philosophy, 43 (suppl.): 1-19.

Anscombe, G. E. M.

1997 "Modern Moral Philosophy." In Virtue Ethics. Edited by R. Crisp and M. Slote. Oxford: Oxford University Press, pp. 26-44.

Berges, S.

Unpublished "Plato's Statesman and Contemporary Virtue Jurisprudence."

2004 "Virtue and the Laws: The Parent Analogy in Plato's Crito." Yeditepe' de Felsefe, 3: 271-87.

Chan, J.

2000 "Legitimacy, Unanimity, and Perfectionism." Philosophy and Public Affairs, 29, 1: 5-42.

Crisp, R., and M. Slote

1997 “Introduction.” In Virtue Ethics. Edited by R. Crisp and M. Slote. Oxford: Oxford University Press, pp. 1-25.

Driver, J.

1996 "The Virtues and Human Nature." In How Should One Live? Edited by R. Crisp. Oxford: Oxford University Press, pp. 111-29.

Foot, P.

Griffin, J.

1978 Virtues and Vices. Oxford: Blackwell.

1986 Well Being: Its Meaning, Measurement and Moral Importance. Oxford: Clarendon Press.

Hamlin, A.

1993 "Welfare." In A Companion to Contemporary Political Philosophy. Edited by B. Goodin and P. Pettit. Oxford: Blackwell, pp. 651-64.

Huby, P.

1957 “The Menexenus Reconsidered.” Phronesis, 2: 104-14.

Hursthouse, R.

1996 "Normative Virtue Ethics." In How Should One Live? Edited by R. Crisp. Oxford: Oxford University Press, pp. 19-36.

Kahn, C.

1999 On Virtue Ethics. Oxford: Oxford University Press.

1963 "Plato's Funeral Oration: The Motive of the Menexenus." Classical Philology, 58, 4: 220-34.

Korsgaard, C.

1999 "Self-Constitution in the Ethics of Plato and Kant." Journal of Ethics, 3: 1-29. 
Locke, J.

1952 The Second Treatise of Government. Indianapolis, IN: BobbsMerrill.

Mill, J. S.

1991 On Liberty and Other Essays. Oxford: Oxford University Press.

Monoson, S.

1998 "Remembering Pericles: The Political and Theoretical Import of Plato's Menexenus." Political Theory, 26, 4: 489-513.

Nussbaum M.

1992 "Human Functioning and Social Justice: In Defence of Aristotelian Essentialism." Political Theory, 20: 202-46.

1996 For Love of Country: Debating the Limits of Patriotism. Boston: Beacon Press.

1997a "Kant and Stoic Cosmopolitanism." The Journal of Political Philosophy, 5, 1: 1-25.

1997b Cultivating Humanity. Cambridge, MA: Harvard University Press.

2000 "Duties of Justice, Duties of Material Aid: Cicero's Problematic Legacy.” The Journal of Political Philosophy, 8, 2: 176-206.

2003 “Compassion and Terror." Daedalus, Winter: 10-26.

Plato

1989 The Collected Dialogues. Translated by B. Jowett. Edited by E. Hamilton and H. Cairns. Princeton: Princeton University Press.

Raz, J.

1986 The Morality of Freedom. Oxford: Oxford University Press.

Slote, $\mathrm{M}$.

1995 "Agent-Based Virtue Ethics." Midwest Studies in Philosophy, 20: $83-101$.

1999 "Virtue Ethics." In Three Methods of Ethics: A Debate, by M. Baron, P. Pettit, and M. Slote. Oxford: Blackwell, pp. 175-238.

2001 "War Crimes and Virtue Ethics." In War Crimes and Collective Wrongdoings. Edited by A. Jokic. Oxford: Blackwell, pp. 77-85.

Taylor, A. E.

1960 Plato: The Man and His Work. London: Methuen. 